\title{
Charakterystyka stresu ekologicznego i różnice indywidualne $w$ radzeniu sobie $z$ nim na przykładzie osób przebywających w więzieniu*
}

\section{Wprowadzenie}

Więzienia należą do jednych z najbardziej kontrowersyjnych instytucji, które stworzył człowiek. Stało się to wtedy, gdy narodziła się kara pozbawienia wolności. W więzieniach współczesnego świata przebywają setki tysięcy osób. Skazani ci, zróżnicowani pod względem psychologicznym, społecznym i kulturowym, muszą czy im to się podoba, czy nie, żyć, pracować oraz odpoczywać na ograniczonej przestrzeni w oderwaniu od swoich dotychczasowych warunków ekologicznych.

Stres występujący w sytuacji izolacji więziennej spowodowany jest drastyczną i długoterminową zmianą warunków ekologicznych, niezbędnych do normalnego funkcjonowania. Ow stres zwany ekologicznym związany jest głównie z ograniczeniem ilości i różnorodności napływających bodźców z naturalnego środowiska życia, ograniczeniem przestrzeni życiowej, zawężonej do wyraźnie niewielkiego obszaru oraz ograniczeniem bezpośrednich kontaktów społecznych wyłącznie do tych osób, które przebywają w izolacji.

Długotrwały pobyt $\mathrm{w}$ więzieniu wiąże się $\mathrm{z}$ niemożnością realizacji szeregu potrzeb, do realizacji których człowiek był przyzwyczajony, jak np. potrzeby samorealizacji, poczucia własnej wartości, bezpieczeństwa, miłości, seksualna, kontaktów z innymi ludźmi, itp.

W obliczu konfrontacji z tego typu stresem ekologicznym człowiek podejmuje aktywność mającą na celu albo zminimalizowanie niektórych źródeł stresu, albo jeśli to się nie udaje, zmniejszenie skutków odczuwanego stresu poprzez stosowanie różnorodnych sposobów i strategii radzenie sobie ze stresem.

* Fragmenty pracy były częściowo wykorzystane w innym artykule, poświęconym problemom stresu egzystencjalnego (por. Terelak,J. Matulewicz E., Steckiewicz E., Determinanty osobowe radzenia sobie ze stresem egzystencjalnym związanym z zagrożeniem wolności osobistej. Zeszyty Naukowe WSSM, 2006, 7(13), 10-41). 
Przedstawione w niniejszej pracy rozważania i wyniki badań empirycznych są próbą ilustracji kosztu psychologicznego jaki człowiek ponosi znajdując się w przymusowej sytuacji stresu ekologicznego oraz sposobów radzenia sobie z tą sytuacją, a także niektórych zmiennych osobowościowych, modyfikujących zarówno ponoszony koszt psychologicznych jak i sposoby zaradcze.

Jedną z takich determinant jest umiejscowienie poczucia kontroli (locus of control), która na podstawie dostępnych badań (Drwal, 1995) sprawia, że osoby prezentujące wewnętrzne poczucie kontroli efektywniej radzą sobie w długotrwałych sytuacjach stresowych, ponosząc przy tym mniejszy koszt emocjonalny. Podjęta tematyka wydaje mi się ważna, poniewaź może być przydatna w próbie wyjaśnienia psychologicznych mechanizmów zaburzeń funkcjonowania osób zmuszonych do długotrwałego przebywania $\mathrm{w}$ drastycznie zmienionych warunkach ekologicznych oraz przewartościowania oczekiwań od tzw. procesu resocjalizacji osób uwięzionych.

\section{Psychologiczna charakterystyka izolacji więziennej}

Stres ekologiczny można zdefiniować jako określony układ relacji między jednostką a ekologią w jakiś sposób dla niej zamknięty. Otoczenie to wskutek obiektywnie istniejących w nim barier, zarówno o charakterze fizycznym jak i społecznym, poważnie ogranicza lub wręcz przerywa bezpośrednie, a często i pośrednie relacje jednostki z jej dotychczasowym, otwartym środowiskiem. Istotą pojęcia stresu ekologicznego jest zawieszenie bądź zerwanie relacji. W tym szerokim znaczeniu jest to zarówno sytuacja separacji od środowiska, do którego człowiek był uprzednio przystosowany, jak również sytuacja ograniczenia swobody działania, a także sytuacja separacji od normalnych źródeł informacji i stymulacji. W psychologii społecznej istnieje wiele szczegółowych terminów, definiujących stopień bariery odgradzającej człowieka od „świata zewnętrznego": deprywacja sensoryczna, deprywacja percepcyjna, izolacja społeczna, uwięzienie, itp. (Plopa 1996, Terelak, 1982, 2001).

Ciosek (1993) wskazuje na fakt, że struktura i funkcje zakładu karnego stwarzają dla więźniów szczególną i długotrwałą sytuację trudną i podaje za T. Tomaszewskim propozycję podziału sytuacji trudnych, która zakłada występowanie następujących grup tych sytuacji: deprywacje, przeciążenia, utrudnienia, zagrożenia i konflikty.

Deprywacje to sytuacje, w których człowiekowi jest brak pewnych, zewnętrznych w stosunku do niego elementów o charakterze fizycznym (np. pokarmu) lub psychicznym (np. kontaktu z innymi ludźmi). W zależności od rodzaju brakujących elementów mówi się o deprywacji pokarmowej, seksualnej czy sensorycznej. 
Przeciążenia to sytuacje, w których jeden z elementów danej sytuacji - zadanie, nie jest dostosowany do warunków działania jednostki lub jej możliwości fizycznych i psychicznych.

Utrudnienia stanowią sytuacje, w których występuje zmiana zwykłych warunków działania czy wykonania czynności w wyniku pojawienia się w sytuacji przeszkód lub braków o charakterze albo wewnętrznym (np. choroba), albo zewnętrznym (np. niemożność opuszczenia pomieszczenia). Frustracja to znane określenie dla tego typu sytuacji trudnych.

Zagrożenia to sytuacje, w których występuje większe niż zazwyczaj prawdopodobieństwo naruszenia osobistych wartości o charakterze fizycznym lub psychicznym (np. zdrowia, dóbr materialnych).

Kolejną kategorią sytuacji trudnych są konflikty. Powstają one wówczas, gdy człowiek znajduje się w polu działania przeciwstawnych sił fizycznych lub sprzecznych nacisków o charakterze społecznym lub moralnym.

Uwięzienie jest więc złożoną sytuacją stresową. Ludzie odbywający karę pozbawienia wolności narażeni są bowiem stale na występujące często równocześnie wszystkie opisane sytuacje trudne: deprywację, zagrożenie, frustrację, przeciążenia i konflikty.

B. Waligóra (1984) pisał o realizującej się w warunkach izolacji więziennej nieustającej deprywacji szeregu potrzeb. Autor ten wskazuje, że deprywacji ulegają m. in. potrzeba kontaktu emocjonalnego, potrzeba seksualna, partnerstwa, godności osobistej, niezależności oraz intymności.

Społeczność więzienną tworzą więźniowie i służba więzienna. Jedni i drudzy posiadają szereg cech indywidualnych (np. wiek, cechy osobowości), które określają to jak spostrzegają oni swoją sytuację. Jedni i drudzy dokonują też nieustannej swoistej interpretacji tej sytuacji i formulują antycypację możliwych zdarzeń. Cechy środowiska fizycznego i społecznego oraz podkultura więzienna prowadzą jakby obligatoryjnie do powstawania licznych sytuacji trudnych nakładających się na pierwotną sytuację izolacji osób uwięzionych. Przeciętny człowiek posiada duże możliwości adaptacyjne, jednak owe sytuacje trudne (głównie deprywacje) mogą stanowić dla niego duży problem. Negatywne emocje generowane przez te sytuacje kumulują się i powodują w efekcie uogólniony stan napięcia wewnętrznego zwany stresem.

Minimalizacji dolegliwości wynikających z izolacji więziennej służy podkultura więzienna tworzona prawdopodobnie we wszystkich zakładach penitencjarnych. Odległymi, lecz poważnymi następstwami długotrwałego stresu więziennego dotykającymi więźniów są ich nawykowo stosowane mechanizmy obronne, zaburzenia psychosomatyczne oraz poważne zaburzenia kontaktów z innymi ludźmi (Ciosek, 1993). 


\section{1. Środowisko więzienne jako przykład stresu ekologicznego}

T. Tomaszewski (1984) przedstawił interesującą propozycję opisu środowiska i sytuacji. Autor porządkuje układ elementów środowiska według następujących aspektów:

1. Sytuacja jako układ stymulacyjny - uwypukla specyficzne i niespecyficzne działanie stymulacyjne otoczenia.

2. Sytuacja jako układ funkcjonalny - podkreśla wartości, które nadają życiu i działalności człowieka określony kierunek oraz możliwości, które decydują o ich organizacji. Ten wymiar sytuacji może być punktem wyjścia do wyróżnienia sytuacji trudnych, o których była już mowa.

3. Sytuacja jako układ społeczny - akcentuje głównie elementy osobowe, które poprzez normy i reguły wpływają na kształtowanie się wartości i określają możliwości człowieka.

4. Sytuacja jako układ przestrzenno-czasowy. Ten aspekt struktury środowiska czy sytuacji zwraca uwagę na relatywność poprzednich układów oraz fakt, że przestrzenno-czasowa struktura sytuacji może modyfikować funkcje poszczególnych jej elementów bądź całych układów.

Powyższy schemat opisu środowiska został wykorzystany przy charakterystyce środowiska więziennego przeprowadzonej przez M. Cioska (1993). Wyszczególnił on cztery podstawowe jego zdaniem aspekty tego środowiska: społeczny, stymulacyjny, czyli bodźcowy, funkcjonalny i przestrzenno-czasowy.

Aspekt społeczny. Rzeczywistość społeczna zakładu karnego stanowi bardzo ważny, a przy tym trudny do opisania aspekt środowiska. Aspekt ten stanowi poważne źródło stresu nie tylko dla więźniów, ale również dla funkcjonariuszy służby więziennej. Więźniowie i funkcjonariusze, którzy znajdują się w jednostce penitencjarnej, są odpowiedzialni za powstawanie sytuacji wzajemnych zagrożeń zarówno dla cenionych przez siebie wartości fizycznych, jak i psychologicznych. Życie wśród innych więźniów jest dla wielu skazanych źródłem lęku przed utratą swego mienia lub przed staniem się ofiarą napaści ze strony innych. Personel i więźniowie winni są powstawaniu licznych sytuacji konfliktowych i napięć we wzajemnych stosunkach.

Aspekt stymulacyjny. Środowisko więzienne jest nie tylko układem społecznym, ale również pewnym układem bodźców, które decydują o ogólnym poziomie aktywacji człowieka, jego samopoczuciu i poziomie sprawności funkcjonowania. Człowiek działa sprawnie (zarówno fizycznie jak i psychicznie) przy optymalnym dla siebie poziomie aktywacji (Eliasz, 1974; za Ciosek, 1993). W środowisku więziennym ubóstwo stymulacji wynika z ograniczonej przestrzeni życiowej, szarości i architektury budynków i pomieszczeń, przeważnie wysokiego i strzeżonego ogrodzenia, którego funkcją jest uniemożliwianie kontaktu 
uwięzionych ze światem zewnętrznym. Występowanie poczucia nudy, monotonii, bezcelowości wśród uwięzionych należy również wiązać z ograniczoną stymulacją charakteryzującą środowisko więzienne (Ciosek, 1993).

Aspekt funkcjonalny. Aspekt funkcjonalny środowiska więziennego stanowi kolejne źródło stresu. Z indywidualnym systemem wartości i możliwości przeciętnego więźnia są zazwyczaj niezgodne dolegliwości izolacji więziennej. One też są odpowiedzialne za wiele sytuacji trudnych, zwłaszcza deprywacji i frustracji (Terelak 2001). Pozbawienie wolności ogranicza możliwość kontaktów z bliskimi i znajomymi. Refleksyjność więźniów niejako wymuszona izolacją, może u niektórych z nich wyzwalać poczucie winy, wstydu, obawę za los swoich najbliższych (Plopa, 1996). Istotną dolegliwością uwięzienia jest pozbawienie możliwości udogodnień materialnych i usługowych. Jedną z najbardziej przykrych dolegliwości więzienia jest pozbawienie skazanego możliwości kontaktów heteroseksualnych. Również pozbawienie autonomii, a więc możliwości dokonywania wyboru i podejmowania decyzji oraz przedmiotowe traktowanie stanowi poważną dolegliwość uwięzienia. Jako funkcjonalną cechę izolacji więziennej można też wymienić pozbawienie skazanego poczucia bezpieczeństwa lub stałe zagrożenie jego utraty, totalny sposób sprawowania władzy i kontroli przez personel, ingerujący we wszystkie sfery życia uwięzionych (Ciosek, 1993).

Aspekt przestrzenno-czasowy. Tereny jednostek penitencjarnych są wyraźne wyodrębnione od przestrzeni pozawięziennej. Obszar znajdujący się w obrębie murów więziennych jest też dokładnie podzielony i zazwyczaj stosunkowo niewielki. Samo ograniczenie rozmiaru przestrzeni życiowej sprzyja więc powstawaniu zjawiska obiektywnego przeludnienia więziennego. Przeludnienie w więzieniu jest zwykle stanem długotrwałym i intensywnym. U wielu więźniów występuje poczucie dyskomfortu psychicznego w związku z naruszeniem dystansu interpersonalnego i niemożności - paradoksalnie - wyizolowania się od innych w sytuacji izolacji.

Odczuwanie stresu ekologicznego w postaci izolacji więziennej jest funkcją czasu przebywania w tym ograniczonym środowisku (długość wyroku). Czas spędzany w więzieniu ma swój specyficzny wymiar, jest czymśs wewnętrznym w stosunku do czasu, który płynie na zewnątrz. Czas spędzony w izolacji więziennej jest według skazanych czasem straconym, bezpowrotnie zmarnowanym. Z wolno upływającym czasem więziennym, zwłaszcza w przypadku więźniów odbywających dłuższe wyroki, wiąże się z obawa, że długi pobyt w więzieniu zmieni niekorzystnie ich osobowość i pozbawi zdolności prawidłowego funkcjonowania na wolności (Ciosek, 1986). 


\subsection{Psychologiczne następstwa izolacji więziennej}

Następstwami izolacji więziennej, które dają o sobie znać we wszystkich fazach uwięzienia (choć prawdopodobnie z różnym nasileniem) są: proces stygmatyzacji więźniów, proces standaryzacji, proces degradacji oraz proces depersonalizacji. Zjawiska te dotyczą w mniejszym lub większym stopniu wszystkich uwięzionych osób.

Proces stygmatyzacji rozpoczyna się faktycznie już w fazie dochodzenia i aresztu, kiedy daje się podejrzanemu do zrozumienia, że należy lub może należeć do przestępczej mniejszości społecznej. Utrata wolności jest dla wielu osób dowodem ich moralnego odrzucenia i potępienia przez wolne społeczeństwo. Kolejny etap stygmatyzacji odbywa się już w instytucji zamkniętej, która posiada właściwe jej prawa i środki dalszego etykietyzowania tych, którzy znaleźli się w jej obrębie. Przez cały okres uwięzienia, a często również po wyjściu na wolność, przypomina się człowiekowi, że utracił status normalnego obywatela i został zaliczony do kategorii przestępców. W niektórych przypadkach stygmatyzacja może przyspieszać proces negatywnej, trwałej identyfikacji z normami podkultury więziennej.

Procesowi standaryzacji podlegają wszystkie osoby pozbawione wolności. Wynika on bezpośrednio $\mathrm{z}$ zawartych $\mathrm{w}$ regulaminie więziennym form postępowania z uwięzionymi. Nakazują one uniformizację ubioru, określają osobnymi przepisami ilość i rodzaj mienia prywatnego więźnia oraz przewidują dla wszystkich jednakowy sposób zaspokajania podstawowych potrzeb. Potrzebą każdego człowieka jest pragnienia bycia kimś niepowtarzalnym. Proces standaryzacji wywołuje poczucie utarty swojej godności i indywidualności (Plopa, 1996).

Proces degradacji związany jest $z$ tym, że człowiek pozbawiony wolności staje się często przedmiotem manipulacji tak ze strony funkcjonariuszy, jak i silniejszych więźniów. Na proces ten składają się sytuacje poniżania, upokarzania i znieważania godności własnej.

Proces depersonalizacji wiąże się $\mathrm{z}$ wyżej wymienionymi zjawiskami: naznaczaniem, uniformizacją i degradacją. Jest to efekt długotrwałego procesu interakcyjnego wyznaczonego przez cechy sytuacji i zmienne podmiotowe jednostki. Depersonalizacja oznacza subiektywne doznanie wewnętrznej przemiany przeżywanej jako poczucie obcości lub wręcz nierealności siebie (Ciosek, 1993). Zjawisko to może prowadzić do zmian osobowości więźniów, które dotyczą głównie obrazu samego siebie. Postępowi procesu depersonalizacji w więzieniu sprzyjają takie konsekwencje izolacji jak: zawieszenie na przyszłość planów osobistych dotyczących życia rodzinnego i zawodowego; pozbawienie możliwości podejmowania samodzielnych decyzji; brak potrzeby planowania codziennych działań, które formułuje administracja jednostki (Ciosek, 1993). 
Badanie skutków przebytej izolacji więziennej nie jest proste z uwagi na to, że zależą one od wielu czynników, między innymi od osobowości więźnia, prezentowanych przez niego strategii radzenia sobie ze stresem, czasu i warunków odbywania kary, przyczyn, które spowodowały stan uwięzienia.

Według B. Waligóry (1995) skutki izolacji wyrażają się we względnie trwałych odkształceniach osobowości i tendencjach do utrwalania się zachowań i reakcji powstałych w izolacji, złym samopoczuciu, stanach apatii i depresji, obniżeniu napędu psychoruchowego, zaburzeniach w sferze stawianych i realizowanych celów, kontaktów z innymi ludźmi i ocen rzeczywistości, skrajnej introwertyzacji, zaburzeń instynktu samozachowawczego i zamachach samobójczych, występowaniu epizodów, a także rozwijających się procesów psychotycznych, dolegliwości i chorób psychosomatycznych.

E. Goffman (1975) wyróżnił pięć technik radzenia sobie z dolegliwościami izolacji więziennej: wycofanie się, bunt, zadomowienie, konwersja i zimna kalkulacja. Wycofywanie się to typ strategii unikowych polegających na odcięciu się od realnego, przykrego otoczenia z jednoczesną koncentracją na sobie, ucieczką w marzenia, świat fikcji. Może to prowadzić do nadmiernego egocentryzmu, a nawet depersonalizacji i autyzmu. Z kolei taktyka buntu przybiera postać bądź zdecydowanej i jawnej postawy oporu i wrogości wobec personelu bądź ukrytej niechęci znajdującej wyraz w uczestnictwie w strukturach nieformalnych. Zwykle obie te postacie przenikają się wzajemnie. Zadomowienie to kolejny typ przystosowania, bardziej typowy dla recydywistów, polega na zapewnieniu sobie w miarę znośnych warunków egzystencji poprzez optymalne w tych warunkach funkcjonowanie. Osoby realizujące ten typ strategii to ludzie nie przeżywające szoku uwięzienia, odporne na sytuacje trudne, a przy tym ujmujące i usłużne. Natomiast konwersja to typ przystosowania, który polega na wręcz idealnym podporządkowaniu się regulaminowi i personelowi, należy jednak podkreślić, że ta uległość jest często pozorem. Wreszcie zimna kalkulacja to kombinacja różnych sposobów adaptacji więziennej, głównie zadomowienia i konwersji w celu zdobycia możliwie maksymalnych w tych warunkach gratyfikacji.

\section{2. „Locus of control” jako zmienna osobowościowa modyfikująca tolerancję stresu ekologicznego}

Zgodnie z teorią społecznego uczenia się Rottera (1990), zachowanie człowieka jest detreminowane przez szereg zmiennych, które można ująć w trzy główne klasy czynników: oczekiwania, wzmocnienia oraz sytuacje psychologiczne. W procesie uczenia się jednostka zdobywa wiedzę o tym, że jedne wzmocnienia mają dla niej większą wartość ze względu zaspokojenie potrzeb niż inne, uczy się tzw. wartości wzmocnień. Sytuacja psychologiczna może zawierać w sobie wi- 
doczne dla jednostki możliwości wyboru alternatywnych zachowań ze względu na oczekiwaną wartość wzmocnienia albo może być sytuacją nie dającą takich możliwości wyboru.

Człowiek może zaspokoić swoje potrzeby dzięki różnym zachowaniom instrumentalnym, a wzmocnienia uzyskiwane dzięki zachowaniu zwiększają oczekiwanie, że w przyszłości po takim zachowaniu następować będą takie same wzmocnienia (Drwal, 1978). Oczekiwanie jest tu definiowane jako prawdopodobieństwo, z jakim jednostka oczekuje, że w danej sytuacji rezultatem podjętego przez nią zachowania będzie uzyskanie określonego wzmocnienia.

Można wyróżnić dwa rodzaje oczekiwań. Jeden z nich to tzw. oczekiwania zgeneralizowane. Są one uogólnieniem dotychczasowych doświadczeń jednostki w zakresie relacji między podejmowanym działaniem a uzyskaniem pożądanego wzmocnienia. Jeżeli większość zachowań człowieka w różnych sferach jego działania prowadziła do uzyskania pożądanych wzmocnień, to zgeneralizowane oczekiwanie uzyskuje postać wysokiego prawdopodobieństwa uzyskania pożądanego wzmocnienia za pośrednictwem danego zachowania.

Drugi rodzaj oczekiwań to oczekiwania specyficzne. Kształtowane są one dotychczasowymi doświadczeniami dotyczącymi tylko pewnego wycinka podejmowanych działań, konkretnych sytuacji.

Wymienione dwa rodzaje oczekiwań oddziałują na siebie wzajemnie, a ostateczne oczekiwanie uzyskania pożądanego wzmocnienia jest wypadkową ich obu. Udział oczekiwań zgeneralizowanych jest większy w sytuacjach względnie nowych, natomiast oczekiwań specyficznych w sytuacjach, z którymi jednostka dotychczas miała już określone doświadczenia.

Oczekiwanie związku między zachowaniem a wzmocnieniem zależeć będzie od stopnia w jakim wzmocnienia (nagrody i kary) warunkowane są instrumentalnymi czynnościami człowieka. Wartość i prawdopodobieństwo wzmocnienia są zależne nie tylko od danej jednostki, lecz również od sytuacji. W pewnych sytuacjach wzmocnienia są zależne od zachowania człowieka, a w innych będą zależały od czegoś co jest poza jego kontrolą.

Ogół sytuacji, z jakimi spotyka się człowiek, można umieścić na dwóch biegunach, od takich, gdzie człowiek w pełni sprawuje kontrolę nad wzmocnieniami, gdzie rezultaty działań zależą od jego sprawności w dążeniu do celu (sytuacje sprawnościowe), do takich sytuacji, gdzie nie ma on żadnego wpływu na wzmocnienia, gdzie rezultaty zależą od czynników losowych, od innych ludzi, czy od jeszcze innych czynników zewnętrznych (sytuacje losowe).

W przewidywaniu zachowania człowieka ważne jest, aby zwrócić uwagę na sposób spostrzegania danej sytuacji przez jednostkę. Obiektywne cechy tej sytuacji są mniej istotne (Drwal, 1995, s. 228).

Poczucie wewnętrznej lub zewnętrznej kontroli odnosi się do oczekiwań, jakie mają ludzie, dotyczących tego, w jakim stopniu wzmocnienie lub wynik 
ich zachowania uwarunkowane są ich własnym zachowaniem bądź osobistymi zdolnościami. Względnie odnosi się do oczekiwań dotyczących stopnia, w jakim wzmocnienie lub wynik są funkcją losu, przeznaczenia, szczęścia czy też są po prostu nieprzewidywalne (Rotter, 1990).

Trwałe i zgeneralizowane oczekiwanie dotyczące lokalizacji kontroli wzmocnień jest indywidualną właściwością człowieka i można je traktować jako wymiar osobowości, jako kontinuum od zgeneralizowanego poczucia kontroli zewnętrznej do zgeneralizowanego poczucia kontroli wewnętrznej.

Osoby z poczuciem kontroli wewnętrznej wierzą, że wszystko, co się im przydarzyło i może przydarzyć, jest następstwem ich osobistych działań, za które ponoszą odpowiedzialność. Jeśli spotyka ich coś dobrego, radosnego, szczęśliwego, przypisują to swoim działaniom, jeśli spotyka ich krzywda, nieszczęście czy inne niepowodzenie, biorą również za nie odpowiedzialność. Ludzie o wewnętrznym poczuciu kontroli są przekonani, że to oni tworzą kształt swojego życia.

Osoby przejawiające poczucie kontroli wewnętrznej można scharakteryzować następująco: traktują życie zadaniowo, wykazują znaczny realizm, nastawieni są na odbiór nowych informacji o sobie i świecie w celu wykorzystania ich w konkretnym działaniu, nie przywiązują wagi do opinii innych ludzi, ale kierują się własną samokontrolą, wykorzystują poprzednie doświadczenia przy realizacji aktualnych zadań życiowych, wykazują dość dobrze rozwinięte poczucie odpowiedzialności, wykazują trudności w przystosowaniu się do otoczenia, które wolą raczej zmieniać, niż zmieniać siebie, są odporni na stres i frustrację (Ostrowska, 1986).

Z kolei osoby z poczuciem kontroli zewnętrznej są przekonani o braku osobistego wpływu na efekty swoich działań, zarówno sukcesy i niepowodzenia. Ludzie ci sukcesy tłumaczą szczęśliwym trafem, a krzywdy, niepowodzenia oraz porażki złym losem, fatum, czynnikami zewnętrznymi. Nie widzą związku między zachowaniem a jego skutkami, nie odczuwają poczucia sprawstwa, są przekonani o swojej niemocy i bezsilności wobec zadań, jakie stawia im życie. Poczucie umiejscowienia kontroli kształtuje się w procesie społecznego uczenia się, $\mathrm{w}$ toku rozwoju (Szmigielska, 1999, Krasowicz i Kurzyp - Wojnarska, 1987).

Poczucie umiejscowienia kontroli może w pewnym zakresie ulegać zmianie. Phares (1976; za Ostrowska, 1986) przytacza wyniki badań Kiehlbucha obrazujące poziom umiejscowienia kontroli w populacji więźniów w zależności od okresu pobytu w więzieniu. Okazuje się, że na początku odbywania kary pozbawienia wolności więźniowie wykazują wyższy poziom kontroli zewnętrznej, w okresie środkowym jest on na poziomie przeciętnym i wreszcie w końcowym stadium, poprzedzającym okres opuszczenia więzienia wykazują ponownie wyższy poziom poczucia kontroli zewnętrznej. Wynik ten wskazuje, że poziom umiejscowienia kontroli może być silnie związany z aktualną sytuacją jednostki, z jej możliwością osiągania założonych celów za pomocą manipulowania, postawą podporządko- 
wania się lub ujawniania niezależności. Zarówno w początkowym, jak i końcowym okresie pobytu w zakładzie karnym (więzieniu), ze względu na realizację innych celów (potrzeb), zależność od innych, a tym samym podporządkowanie się i wykazywanie bierności, jest skuteczniejsza niż ujawnianie samodzielności.

\section{Radzenie sobie ze stresem jako wyuczona forma adaptacji do warunków środowiska}

Za podstawę teoretyczną stresu ekologicznego przyjęto interakcyjną koncepcję Richarda Lazarusa i Susan Folkman (1984), według których w opisie stresu i radzeniu sobie z nim kluczowe znaczenie przypisuje się subiektywnej ocenie poznawczej relacji jaka zachodzi pomiędzy osobą a środowiskiem. To podmiot rozstrzyga o tym, czy dana relacja jest stresowa, nie zaś obiektywne cechy tej sytuacji. Lazarus wyróżnia dwa rodzaje oceny poznawczej: ocenę pierwotną i ocenę wtórną. Ocena pierwotna to proces oceniający, czy docierająca do nas informacja na temat cech środowiska jest zagrażająca naszemu dobrostanowi czy też nie. Informacje ocenione jako pozytywne lub obojętne nie są zaliczane do kategorii stresorów. Jeśli informacja została oceniona jako zagrażająca lub jeśli oceniliśmy, że nie posiadamy wystarczających zasobów zaradczych, wówczas powstaje stan napięcia wywołujący określone procesy psychofizjologiczne i ich korelaty emocjonalne (np. lęk) oraz rozpoczyna się proces radzenia sobie ze stresem (Terelak, 2001). Radzenie sobie ze stresem posiada trzy odniesienia znaczeniowe, które raczej uzupełniają się, niż wykluczają; radzenie sobie może być rozpatrywane jako: proces, strategia i styl (Heszen - Niejodek, 2000). Styl jest traktowany jako trwała dyspozycja podmiotu do określonego zmagania się z sytuacjami stresowymi. Strategia to określone działania, jakie jednostka podejmuje w konkretnej sytuacji stresowej. Proces radzenia sobie ze stresem traktowany jest jako ciąg zmieniających się w czasie strategii (Szczepaniak, Strelau i Wrześniewski, 1996).

Determinantami radzenia sobie, podobnie jak każdego innego celowego zachowania się człowieka, są dwojakiego rodzaju czynniki: sytuacyjne i osobowe. Samo radzenie sobie jest dynamicznym, rozwijającym się w czasie procesem, na który składają się mniejsze jednostki aktywności, nazywane strategiami lub sposobami radzenia sobie. Następstwa konfrontacji stresowej, czyli skutki pozostałe i wynikłe po jej zakończeniu mają również charakter złożony. Za przykład mogą służyć następstwa bezpośrednie i odległe, następstwa dotyczące obiektywnej sytuacji stresowej, lub człowieka - podmiotu tej sytuacji, a w obrębie tych ostatnich - skutki odnoszące się do poziomu biologicznego, psychologicznego i społecznego (Heszen - Niejodek, 1997).

Specyficzne dla jednostki strategie radzenia sobie nie są wrodzone, ale stanowią formy zachowania nabytego. Wynika $z$ tego, że repertuar radzenia sobie 
powstaje i rozwija się zgodnie z ogólnymi zasadami uczenia się. W trakcie procesu radzenia sobie możliwe jest pojawienie się nowych form aktywności zaradczej wskutek okoliczności zewnętrznych lub zamierzonych wysiłków człowieka celowo kształtującego swoje zachowanie. Niektóre z nich mogą utrwalić się jako nowe strategie radzenia sobie, zwłaszcza jeżeli okazały się skuteczne w przezwyciężaniu stresu.

W literaturze przedmiotu można wyróżnić dwa rodzaje kategorii, którym przypisuje się pojęcie stylu radzenia sobie. Do pierwszej należą określenia traktujące styl jako pojedynczy wymiar, dyspozycję lub cechę jednostki. W taki sposób styl został określony przez H. W. Krohhne’a oraz przez S. H. Miller (Wrześniewski, 2000). W drugiej grupie mieszczą się definicje traktujące styl jako określony zbiór dyspozycji czy właściwości jednostki. W tym ujęciu styl ma charakter złożony, wielowymiarowy. Przykładem takiego pojmowania stylu jest koncepcja N. S. Endlera i J. D. A. Parkera.

W niniejszej pracy odwołamy się do stylów radzenia sobie ze stresem w ujęciu Endlera i Parkera (za Wrześniewski, 2000), którzy częściowo nawiązując do funkcji, jakie według R. S. Lazarusa radzenie sobie ma pełnić radzenie sobie ze stresem wyróżniają: styl skoncentrowany na zadaniu, styl skoncentrowany na emocjach oraz styl skoncentrowany na unikaniu.

Styl skoncentrowany na zadaniu charakterystyczny jest dla osób, które w sytuacjach stresowych podejmują wysiłki zmierzające do rozwiązania problemu, poprzez poznawcze przekształcanie lub próby zmiany sytuacji.

Styl skoncentrowany na emocjach charakteryzuje osoby, które w obliczu stresu koncentrują się na sobie, na własnych przeżyciach emocjonalnych, takich jak: złość, poczucie winy, napięcie. Osoby takie przejawiają też tendencję do fantazjowania i myślenia życzeniowego. Działania takie mają na celu zmniejszenie napięcia emocjonalnego związanego z sytuacją stresową. Czasami jednak mogą zwiększać poczucie stresu, wzrost napięcia lub przygnębienie.

Styl skoncentrowany na unikaniu cechuje osoby, które w sytuacjach stresowych wykazują tendencję do wystrzegania się myślenia, przeżywania i doświadczania tych sytuacji. Styl ten może przyjmować dwie formy: angażowanie się w czynności zastępcze (np. objadanie się, oglądanie telewizji, sen, myślenie o sprawach przyjemnych) lub poszukiwanie kontaktów towarzyskich.

\section{Umiejscowienie poczucia kontroli jako determinanta radzenie sobie ze stresem ekologicznym}

Poczucie umiejscowienia kontroli traktowane jest jako istotna zmienna wpływająca na funkcjonowanie jednostek w złożonych, stresujących dla nich sytuacjach życiowych. 
Wiele dotychczas przeprowadzonych badań wskazuje, że osoby wierzące w osobistą moźliwość wpływania na stresujące zdarzenia życiowe generalnie lepiej potrafią je opanować, są efektywniejsze w zmaganiu się z nimi. Ludzie $z$ wewnętrznym poczuciem umiejscowienia kontroli w sytuacjach określanych jako trudne mają większe poczucie odpowiedzialności za swoje postępowanie, poszukują informacji na temat zagrożenia, bardziej racjonalnie niż emocjonalnie radzą sobie z problemem (Plopa, 1996).

Wyniki badań wskazują, że osoby z zewnętrznym poczuciem kontroli gorzej funkcjonują w sytuacjach stresowych. Osoby prezentujące ten wymiar osobowości najczęściej mają przekonanie o niemożności wpływu na zmianę sytuacji stresowej, stąd też nie wykazują koncentracji na źródle problemu, ale na własnych emocjach. Negatywne wydarzenia życiowe mają bardziej trwały związek z zaburzeniami nastroju u osób zewnętrznie umiejscawiających kontrolę, niż u osób z wewnętrznym poczuciem kontroli (Poprawa, 1996).

M. Petrosky i J. Birkimer (1991; za Łosiak, 1994) pytali swoich badanych o najbardziej stresujące zdarzenie, jakie przytrafiło im się w niedawnej przeszłości i brali pod uwagę ocenę poznawczą, stosowane formy radzenia sobie oraz umiejscowienie poczucia kontroli. Uzyskane wyniki wskazują, że osoby o wewnętrznym poczuciu umiejscowienia kontroli stosowały w większym stopniu strategie polegające na aktywnym działaniu wobec problemu, a w mniejszym - strategie tłumienia. Z kolei osoby o zewnętrznym poczuciu lokalizacji kontroli rzadziej podejmowały aktywne działanie w obliczu problemu. Otrzymano więc różne wzory działania wobec trudności u osób różniących się poczuciem umiejscowienia kontroli.

Także E. Butterfield (1964; za Drwal, 1981) otrzymał wyniki wskazujące, że wewnętrzne poczucie lokalizacji kontroli koreluje z konstruktywnymi reakcjami na frustrację, natomiast poczucie kontroli zewnętrznej z reakcjami intropunitywnymi (oskarżanie siebie i samoagresja).

Susan E. Hahn (2000) badała związek między poczuciem umiejscowienia kontroli a radzeniem sobie ze stresem i reaktywnością w relacjach interpersonalnych. Wyniki tych badań świadczą o tym, że osoby z poczuciem kontroli zewnętrznej stosują częściej sposób radzenia sobie ze stresem oparty na kontaktach emocjonalnych. Z kolei osoby przejawiające wewnętrzne poczucie kontroli częściej stosują radzenie sobie skoncentrowane na problemie.

Karolyn M. Aldwin (1991) w swoich badaniach stwierdziła, że wewnętrzne poczucie kontroli związane jest z przyjmowaniem odpowiedzialności i radzeniem sobie skoncentrowanym na problemie. Zewnętrzne umiejscowienie poczucia kontroli wiąże się z unikaniem sytuacji stresowej i koncentrowaniu się na emocjach.

Pewne badania wskazują, że przekonanie o posiadaniu kontroli osobistej nad rezultatem danej konfrontacji stresowej może w pewnych warunkach wzmagać 
napięcie i negatywne emocje. Stwierdzono, że osoby wewnętrznie umiejscawiające kontrolę doznając porażek bardziej się nimi przejmują niż osoby o zewnętrznym poczuciu kontroli, ponieważ mają większą skłonność do przypisywania ich sobie. W takich okolicznościach wewnętrzne poczucie umiejscowienia kontroli może być przyczyną stresu (Strickland, 1978; za Szmigielska, 1999).

Przekonanie o własnej kontroli osobistej może wpływać na radzenie sobie ze stresem głównie przez procesy oceny poznawczej. Jednocześnie samo radzenie sobie może modyfikować poczucie kontroli osobistej. Sytuacja ta może mieć miejsce przy radzeniu skoncentrowanym na emocjach, które mogą służyć (obok redukcji napięcia) zmianie znaczenia danej sytuacji, a przez to zwiększeniu lub ograniczeniu, bądź zanikowi poczucia kontroli, np. poprzez koncentrowanie się na pozytywnych aspektach negatywnych rezultatów danej konfrontacji, dewaluowanie znaczenia danego zdarzenia, przypisywanie porażki czynnikom zewnętrznym (Ogińska - Bulik, 2000).

W niektórych badaniach podkreśla się, że najbardziej efektywnie radzą sobie ze stresem osoby z umiarkowanym poczuciem umiejscowienia kontroli (Krause, Stryker, 1984; za Plopa 1996).

Hipotezy

Na podstawie przedstawionych powyżej teorii, koncepcji i doniesień z badań można założyć, że istnieje związek między poczuciem umiejscowienia kontroli a stylami radzenia sobie ze stresem ekologicznym. I tak przyjmujemy, że:

1) Osoby o poczuciu kontroli wewnętrznej w większym stopniu preferują styl radzenia sobie skoncentrowany na zadaniu, niż osoby o poczuciu kontroli zewnętrznej.

2) Osoby o poczuciu kontroli zewnętrznej w większym stopniu preferują styl radzenia sobie ze stresem skoncentrowany na emocjach i unikaniu, niż osoby o poczuciu kontroli wewnętrznej.

\section{Materiał i metody badań}

\subsection{Charakterystyka badanej grupy}

Grupę badaną stanowili więźniowie przebywający w zakładzie karnym Aresztu Śledczego w Suwałkach. W zakładzie karnym osadzeni są skazani odbywający karę pozbawienia wolności o długości wyroku nie dłuższym niż pięć lat. W przeważającej części grupę więźniów stanowią skazani za przestępstwa przeciwko mieniu; rozboje oraz za przestępstwa w ruchu drogowym. W okresie przeprowadzenia badań (styczeń - luty 2004) w zakładzie karnym przebywało około 140 więźniów. 
Ogółem badaniom poddanych zostało 120 osób w wieku od 19 do 58 lat. Średnia wieku wynosiła 29 lat. Badani przebywali w więzieniu od 6 miesięcy do 4 lat. Wszyscy więźniowie wyrażali zgodę na udział w badaniach.

\subsection{Opis metod badań}

- Skala I - E Rottera - do badania poczucia umiejscowienia kontroli w polskiej wersji opracowanej przez J. Karyłowskiego w Laboratorium Technik Diagnostycznych Wydziału Psychologii Uniwersytetu Warszawskiego. Skala ta bada wymiar osobowości będący tendencją człowieka do spostrzegania związku przyczynowego między własnymi zachowaniami a skutkami tych zachowań. Wymiar ten tworzy kontinuum, którego jeden kraniec zajmują osoby o zewnętrznym poczuciu umiejscowienia kontroli, zaś drugi - osoby o wewnętrznym poczuciu lokalizacji kontroli (Drwal, 1978).

- Kwestionariusz CISS - (Coping Inventory for Stressfull Situations) został opracowany w 1986 r. przez Normana S. Endlera i Jamesa D. A. Parkera. Polską adaptację CISS przeprowadzili P. Szczepaniak, K. Wrześniewski i J. Strelau (1994). Konstrukcja kwestionariusza CISS opiera się na założeniach interakcyjnego modelu radzenia sobie ze stresem Lazarusa i Folkman. Styl radzenia sobie ze stresem interpretuje się jako typowy dla danej jednostki sposób zachowania się w różnych sytuacjach stresowych (Borkowski, 2001). Kwestionariusz CISS składa się z trzech skal, z których każda składa się z 16 pozycji, badających następujące style radzenia sobie ze stresem określających: styl radzenia sobie skoncentrowany na zadaniu, na emocjach oraz na unikaniu (Endler, Parker, 1990; za Wrześniewski, 2000).

\section{Wyniki badań i dyskusja}

W toku analizy statystycznej porównano preferencje odnośnie do poszczególnych stylów radzenia sobie ze stresem u osób o wewnętrznym oraz zewnętrznym poczuciu kontroli. Oszacowano także związki pomiędzy wiekiem a lokalizacją kontroli.

W tabeli 1 przedstawiono zależności między „locus of control" a stopniem preferencji poszczególnych stylów radzenia sobie ze stresem. 
Charakterystyka stresu ekologicznego i różnice indywidualne w radzeniu sobie z nim...

Tabela 1. Zwiazek, ,locus of control“ ze stylami radzenia sobie ze stresem $(N=108)$.

\begin{tabular}{|c|c|c|c|c|}
\hline \multirow{2}{*}{$\begin{array}{c}\text { Style radzenia } \\
\text { sobie }\end{array}$} & \multicolumn{2}{|c|}{ Korelacja Pearsona } & \multicolumn{2}{c|}{ Korelacja Spearmana } \\
\cline { 2 - 5 } & $\mathrm{R}$ & $\mathrm{P}$ & $\mathrm{Rho}$ & $\mathbf{p}$ \\
\hline SSZ & $-0,24$ & $0,010^{*}$ & $-0,19$ & $0,039^{*}$ \\
\hline SSE & 0,26 & $0,006^{\star *}$ & 0,26 & $0,005^{\star *}$ \\
\hline SSU & 0,29 & $0,002^{* *}$ & 0,28 & $0,003^{\star *}$ \\
\hline PKT & 0,06 & 0,519 & 0,04 & 0,676 \\
\hline ACZ & 0,32 & $0,001^{* * *}$ & 0,31 & $0,001^{\star *}$ \\
\hline
\end{tabular}

${ }^{* * *} \mathrm{p}<0,001$

$* * \quad \mathrm{p}<0,01$

- $\mathrm{p}<0,05$

Istnieje istotny statystycznie związek pomiędzy otrzymanym wynikiem w skali I - E Rottera a stopniem preferencji zadaniowego stylu radzenia sobie ze stresem. Wraz ze wzrostem poczucia kontroli zewnętrznej, maleje stopień preferencji zadaniowego stylu radzenia sobie ze stresem.

Występuje także istotna statystycznie dodatnia korelacja między otrzymanym wynikiem w skali I - E Rottera a stopniem preferencji stylu skoncentrowanego na emocjach. Wraz ze wzrostem poczucia kontroli wewnętrznej rośnie stopień preferencji emocjonalnego stylu radzenia sobie ze stresem. Można również stwierdzić występowanie związku między „locus of control“ a stopniem preferencji stylu skoncentrowanego na unikaniu. Badani o poczuciu kontroli zewnętrznej w większym stopniu preferują styl skoncentrowany na unikaniu i angażowaniu się w czynności zastępcze, niż badani o poczuciu kontroli wewnętrznej.

Nie stwierdzono związku między stylem poszukiwanie kontaktów towarzyskich a poczuciem kontroli wewnętrznej i zewnętrznej.

Przystępując do dyskusji otrzymanych wyników należy stwierdzić, że zgodnie z przedstawionym wcześniej przeglądem badań wynika, że umiejscowienie poczucia kontroli ma zawiązek z wyborem środków zaradczych stosowanych w obliczu stresu ekologicznego. Otrzymane w tej pracy dane wskazują, że sytuacja stresu ekologicznego w postaci izolacji więziennej, mimo prób zaradczych, nie niweluje wprawdzie tego wpływu, lecz znacznie go modyfikuje u ludzi zróżnicowanych pod względem takiej cechy osobowości jak „locus of control”.

Przedstawione wyniki przemawiają za trafnością hipotezy, mówiącej o preferencji stylu radzenia sobie ze stresem skoncentrowanym na zadaniu przez osoby o poczuciu kontroli wewnętrznej, w porównaniu z osobami o poczuciu kontroli zewnętrznej.

Gdy w sytuacji stresowej, a taką z całą pewnością jest sytuacja uwięzienia, człowiek ma możliwość wykonywania pewnych operacji, których celem jest 
uniknięcie zagrożenia czy pozytywne przezwyciężanie takiej sytuacji, to stopień zagrożenia zmniejszy się radykalnie, a efektywność działania będzie większa w porównaniu z sytuacją, gdzie takich możliwości brak. Zagrożenie mierzone subiektywnymi ocenami osoby badanej lub wskaźnikami fizjologicznymi zwykle jest mniejsze, a jej zachowanie w obliczu zagrożenia jest bardziej efektywne wtedy, gdy sądzi ona (słusznie czy nie), że ma kontrolę nad sytuacją (Drwal, 1981).

Poczucie kontroli wewnętrznej sprzyja podejmowaniu różnorodnych działań mających na celu opanowanie trudności, a to $\mathrm{z}$ kolei zwiększa zakres informacji zwrotnych o tym jak sobie z nimi radzić. Badani o poczuciu kontroli wewnętrznej w sytuacji stresowej podejmują ukierunkowany wysiłek zmierzający do rozwiązania problemu, czy to przez poznawcze przekształcenie, czy też aktywną zmianę sytuacji. Przez to lepiej radzą sobie ze swoimi emocjami. Można stwierdzić, że środki zaradcze więźniów o poczuciu kontroli wewnętrznej w obliczu izolacji więziennej nastawione są na zrozumienie swojej sytuacji i efektywne poszukiwanie rozwiązania. Wybór sposobu działania zależny jest bardziej od kompleksowej oceny sytuacji, niz przeżywanych emocji. Po zapoznaniu się z regułami życia więziennego uczą się przewidywać i kontrolować sytuację. Więźniowie ci elastycznie dostosowują się do wymagań sytuacji, wykorzystują swoje mocne strony w podejmowanych działaniach. Badania Goodsteina oraz MacKanziego (za: Ciosek, 1993) wskazują, że uwięzieni o poczuciu kontroli wewnętrznej doświadczają mniej stresu i przejawiają zdecydowanie mniej negatywnych postaw wobec jednostki penitencjarnej niż więźniowie o poczuciu kontroli zewnętrznej. Można przypuszczać, że wpływ na taki stan rzeczy może mieć wybór zadaniowego stylu radzenia sobie $\mathrm{z}$ sytuacją stresową przez więźniów o wewnętrznym poczuciu kontroli.

Również druga z postawionych $w$ tej pracy hipotez znalazła swoje odzwierciedlenie $w$ wynikach przeprowadzonych badań. Zaobserwowano bowiem, że więźniowie o poczuciu kontroli zewnętrznej w większym stopniu preferują styl radzenia sobie ze stresem skoncentrowany na emocjach, niż uwięzieni o poczuciu kontroli wewnętrznej. Brak poczucia kontroli nad otoczeniem wiąże się z oceną sytuacji jako silnego zagrożenia i doświadczania negatywnych emocji, co w konsekwencji prowadzi do stosowania takich środków zaradczych, które uwolnią (chociaż na krótki czas) od tego przykrego stanu. Więźniowie o poczuciu kontroli zewnętrznej w obliczu stresu związanego $\mathrm{z}$ przebywaniem w izolacji penitencjarnej wykazują tendencję do koncentracji na sobie, na własnych przeżyciach emocjonalnych, takich jak lęk, złość, napięcie, bunt. Zdają się oni być bardziej zaprzątnięci własną osobą i walką z przykrymi emocjami towarzyszącymi sytuacji stresowej, niż samą sytuacją. Ludzie ci nie wierzą we własne siły i możliwości zaradzenia zaistniałej sytuacji, w związku z tym może się u nich zaznaczać także tendencja do myślenia życzeniowego, fantazjowania oraz ucieczki w marzenia. Zasadne wydaje się więc przypuszczenie, że mogą oni nie podejmo- 
wać prób zmiany stresowej sytuacji, a jedynie koncentrować się na działaniach obniżających przykre napięcie z nią związane.

Trzecia postawiona w tej pracy hipoteza, mówiąca o większej preferencji stylu radzenia sobie opartego na unikaniu przez osoby o poczuciu kontroli zewnętrznej, w porównaniu z osobami o poczuciu kontroli wewnętrznej została potwierdzona częściowo. Stwierdzono istotną statystycznie różnicę między obiema grupami w preferencji stylu skoncentrowanego na unikaniu oraz angażowaniu się w czynności zastępcze. Nie stwierdzono natomiast różnicy w preferencji stylu poszukiwanie kontaktów towarzyskich między badanymi o poczuciu kontroli wewnętrznej oraz badanymi o poczuciu kontroli zewnętrznej. Obie grupy wykorzystują ten styl w podobnym stopniu.

Z uzyskanych danych wynika, że badani o poczuciu kontroli zewnętrznej w sytuacji izolacji więziennej w większym stopniu stosują styl skoncentrowany na unikaniu, niż osoby o poczuciu kontroli wewnętrznej. Wykazują oni tendencję do wystrzegania się myślenia, przeżywania i doświadczania zaistniałej sytuacji. Przeświadczenie o braku możliwości wpływania na bieg wydarzeń, może być powodem gorszego przystosowania do zaistniałej sytuacji. Uwięzieni o poczuciu kontroli zewnętrznej uważają, że angażowanie się w jakiekolwiek działania nie ma większego sensu, ponieważ żadne działania nie są w stanie wpłynąć na to co się zdarza. Przyjmują więc bierną postawę wobec otaczającej ich rzeczywistości i nie podejmują działań prowadzących do uporania się z problemem. Badani o poczuciu kontroli zewnętrznej próbują pogodzić się z losem i w celu odwrócenia uwagi od zaistniałej sytuacji angażują się w czynności zastępcze, np. oglądanie telewizji, sen, objadanie się, myślenie o sprawach przyjemnych.

Interesujący jest fakt, że w przeprowadzonych badaniach nie stwierdzono różnicy w posługiwaniu się stylem poszukiwanie kontaktów towarzyskich między badanymi o poczuciu kontroli zewnętrznej a badanymi o poczuciu kontroli wewnętrznej. Przyczyną tego stanu rzeczy może być fakt, że uwięzienie w znacznym stopniu ogranicza moźliwość kontaktowania się z bliskimi i znajomymi. Ważne wydaje się również to, iż środowisko więzienne w znaczącym stopniu ogranicza przestrzeń życiową i osobistą więźniów z uwagi na czynnik przeludnienia. Przeludnienie jest zwykle stanem długotrwałym. U wielu więźniów występuje poczucie pogwałcenia sfery prywatności, niemożność odizolowania się od innych. Poczucie zatłoczenia powoduje wzajemne przenikanie się czy zachodzenie sfer przestrzeni osobistych. Sytuacja ta może prowokować agresywną tendencję do uściślania granic terytorium, zamachy na terytoria innych osób (Ciosek, 1993). 


\section{Wnioski}

Mężczyźni o poczuciu kontroli wewnętrznej w sytuacji stresu ekologicznego cechującego się izolacją więzienną w większym stopniu preferują styl radzenia sobie ze stresem skoncentrowany na zadaniu, niż mężczyźni o poczuciu kontroli zewnętrznej również przebywający w izolacji więziennej. I odwrotnie - mężczyźni o poczuciu kontroli zewnętrznej w większym stopniu preferują styl radzenia sobie ze stresem skoncentrowany na emocjach, niż mężczyźni o poczuciu kontroli wewnętrznej również przebywający w izolacji więziennej.

\section{Bibliografia}

ALDWIN, CAROLYN M. (1991). Does age affect the stress and coping process? Implications of age differences in perceived control. Journal of Gerontology, 46 (4), $174-180$.

BORKOWSKI, J. (2001). Radzenie sobie ze stresem a poczucie tożsamości. Warszawa: Wyd. Elipsa.

CIOSEK, M. (1986). Izolacja więzienna a doświadczanie czasu. Przeglq̨ Penitencjarny i Kryminologiczny, 11, $50-61$.

CIOSEK, M. (1993). Izolacja więzienna. Wybrane aspekty izolacji więziennej w percepcji więźniów i personelu. Gdańsk: Wyd. Uniwersytetu Gdańskiego.

DOMAŃSKA-NAJDER, K. (1984). Definicja pojęcia kontroli - przegląd zagadnień. Przegląd Psychologiczny, XXVII, 2, 405 - 421.

DRWAL, R. Ł. (1995). Adaptacja kwestionariuszy osobowości. Warszawa: PWN.

DRWAL, R. Ł. (1981). Osobowość wychowanków zakładów poprawczych. Wrocław: Zakł. Narodowy im. Ossolińskich.

GOFFMAN, E. (1975). Charakterystyka instytucji totalnych, W: W. Derczyński (red): Elementy teorii socjologicznych. Warszawa: PWN.

GLISZCZYŃSKA, X. (1990). Skala I - E w pracy (narzędzie pomiaru poczucia kontroli w pracy), Studia Psychologiczne, 28 (1), 79 - 93.

HAHN, SUSAN, E. (2000). The effects of locus of control on daily exposure, coping and reactivity to work interpersonal stressors: A diary study. Personality and Individual Differences, 29(4), $729-748$.

HESZEN-NIEJODEK, I. (2000). Stres i radzenie sobie główne kontrowersje. W: I. Heszen - Niejodek (red): Człowiek w sytuacji stresu (ss. 12 - 43). Katowice: Wyd. Uniwersytetu Śląskiego.

HESZEN - NIEJODEK, I. (1997). Styl radzenia sobie ze stresem: fakty i kontrowersje. Czasopismo Psychologiczne, 3, 1, 7 - 22.

HOEYST, B. (2001). Kryminologia. Warszawa: Wyd. LexisNexis.

KRASOWICZ, G., KURZYP-WOJNARSKA, A. (1987). Społeczne wyznaczniki poczucia kontroli następstw zdarzeń. Psychologia Wychowawcza, 30, 524- 532.

LAZARUS, R., FOLKMAN, S. (1984). Stress, appraisal, and coping. New York: Springer Pub.Co.

ŁOSIAK, W. (1995). Dynamika emocji i radzenia sobie w stresie psychologicznym, Kraków: Wyd. UJ.

OGINSKA-BULIK, N. (2000). Zasoby osobiste w radzeniu sobie ze stresem. Zeszyty Naukowe WSHE, 8 (13).

OSTROWSKA, K. (1986). Koncepcja umiejscowienia kontroli J. B. Rottera. W: K. Ostrowska, D. Wójcik: Teorie kryminologiczne (ss. 194 - 202). Warszawa: Wyd. ATK.

PLOPA, M. (1996). Stres w izolacji morskiej. Psychospołeczne uwarunkowania. Gdańsk: Wyd. Uniwersytetu Gdańskiego. 
POPRAWA, R. (1996). Zasoby radzenia sobie ze stresem, W: G. Dolińska - Zygmunt (red): Elementy psychologii zdrowia. Wrocław: Wyd. Uniwersytetu Wrocławskiego.

ROTTER, J., B. (1990). Poczucie wewnętrznej vs zewnętrznej kontroli wzmocnień. Nowiny Psychologiczne, 1990, 5- 6, $59-69$.

SPENDEL, Z. (2002). Niektóre metodologiczne i etyczne aspekty psychologicznych badań nad stresem i radzeniem sobie, W: I. Heszen - Niejodek (red): Konteksty stresu psychologicznego. Katowice: Wyd. Uniwersytetu Śląskiego.

SZCZEPANIAK, P., STRELAU, J., WRZEŚNIEWSKI, K. (1996). Diagnoza stylów radzenia sobie ze stresem za pomocą polskiej wersji kwestionariusza CISS Endlera i Parkera. Przegląd Psychologiczny, 39, 1, 187-210.

SZMIGIELSKA, B. (1999). Społeczno - uczeniowa teoria osobowości Juliana B. Rottera, W: A. Gałdowa (red): Klasyczne i wspótczesne koncepcje osobowości (ss 209 - 225). Kraków: Wyd. UJ.

TERELAK, J. F. (1982). Czlowiek w sytuacjach ekstremalnych: Izolacja antarktyczna. Warszawa: Wyd. MON.

TERELAK, J. F. (2001). Psychologia stresu. Bydgoszcz: Oficyna Wyd. Branta.

TOMASZEWSKI, T. (1984). Slady i wzorce. Warszawa: WSiP.

WALIGÔRA, B. (1984) Deprywacja potrzeb u osób pozbawionych wolności, W: B. Hołyst (red): Problemy wspótczesnej penitencjarystyki w Polsce $(56-63)$. Warszawa: Wyd.Prawnicze.

WALIGÓRA, B. (1995). Izolacja i jej następstwa, W: B. Waligóra (red): Elementy psychologii klinicznej $(157$ - 161). Poznań: Wyd. Naukowe UAM.

WRZEŚNIEWSKI, K. (2000). Style a strategie radzenia sobie ze stresem. Problemy pomiaru, W: I. Heszen - Niejodek (red): Cztowiek w sytuacji stresu (ss. 44 - 64). Katowice: Wyd. Uniwersytetu Śląskiego.

\title{
Ecological stress and individual differences in coping stress on persons permanent limits personal freedom
}

\author{
SUMMARY
}

The paper is empirical in character and concerns people's individual conditions of dealing with ecological stress involving permanent limits personal freedom. According to literature data, it is assumed the one should expect relatively stable individual differences in dealing with so defined extreme ecological stress. Different styles of dealing with stress in certain situations for a human are pointed out as well as their individual conditions, which can be useful in the creation of a personality conception of social support in the procesess of cping stress and resocialisation. 